\title{
Variability in growth rates of long-lived black coral Leiopathes sp. from the Azores
}

\author{
M. Carreiro-Silva ${ }^{1, *}$, A. H. Andrews ${ }^{2}$, A. Braga-Henriques ${ }^{1}$, V. de Matos ${ }^{1}$, \\ F. M. Porteiro ${ }^{1}$, R. S. Santos ${ }^{1}$ \\ ${ }^{1}$ Centre of IMAR of the University of the Azores, Department of Oceanography and Fisheries/UAz \& LARSyS Associated
Laboratory, Rua Prof. Dr Frederico Machado, 4, PT-9901-862 Horta, Azores, Portugal \\ ${ }^{2}$ NOAA Fisheries - Pacific Islands Fisheries Science Center, 99-193 Aiea Heights Drive 417 Aiea, Hawaii 96701, USA
}

\begin{abstract}
Five colonies of black coral Leiopathes sp. were collected as bycatch from depths of 293 to $366 \mathrm{~m}$ from the Condor, Açor, and Voador seamounts (Azores region). The colonies had axial diameters between 4.9 and $33.1 \mathrm{~mm}$ and heights between 43 and $175 \mathrm{~cm}$. Their ages and radial growth rates were estimated using radiocarbon dating. Results indicated that the smallest and largest colonies had similar radial growth rates of 5 to $7 \mu \mathrm{m} \mathrm{yr}^{-1}$, whereas the other 3 colonies had grown more rapidly by a factor of 3 to 5 at $\sim 20$ to $30 \mu \mathrm{m} \mathrm{yr}^{-1}$. Colony lifespan ranged between $265 \pm 90$ and $2320 \pm 90 \mathrm{yr}$. Fine-scale sampling along a radial transect from the edge to the center of the 2320 yr old Leiopathes sp. revealed variable growth rates throughout the colony lifespan. Slower radial growth rates of $\sim 4$ to $5 \mu \mathrm{m} \mathrm{yr}^{-1}$ were recorded over the initial $1600 \mathrm{yr}$ and the last $300 \mathrm{yr}$ of its life span, and a period of more rapid growth $\left(20 \mu \mathrm{m} \mathrm{yr}^{-1}\right)$ over the intermediate $400 \mathrm{yr}$ of its life. Variability in radial growth rates among colonies resulted in colony ages that were not linearly correlated to colony axis diameter or height. Our findings of great longevity and slow growth rates for Leiopathes sp. agree with other Leiopathes sp. age and growth studies, indicating that colony and population recovery from damage or removal may take centuries to millennia.
\end{abstract}

KEY WORDS: Antipatharia $\cdot$ Cold-water corals $\cdot$ Deep-sea $\cdot$ Growth $\cdot$ Longevity $\cdot$ Radiocarbon Northeast Atlantic

Resale or republication not permitted without written consent of the publisher

\section{INTRODUCTION}

Deep-sea or cold-water coral ecosystems have have been recognized as important biodiversity hotspots in the deep sea (Roberts et al. 2009). The structural complexity of cold-water corals provides essential habitat that is used during feeding and spawning and as nursery grounds for a range of organisms, including commercially important fish species (Husebø et al. 2002, Reed 2002, Costello et al. 2005, Metaxas \& Davis 2005, Roberts et al. 2009). An added factor that creates a sense of urgency in protecting these unique organisms is their extreme vulnerability to disturbance. Several studies have shown that bottom fishing can damage or destroy cold-water corals, reducing the 3-dimensional complexity of the bottom topography and leading to decreased faunal biodiversity and biomass (Koslow et al. 2001, HallSpencer et al. 2002, Morgan et al. 2005, Althaus et al. 2009, Clark \& Rowden 2009).

Despite the realization of damage to these communities, the recovery of cold-water coral ecosystems from bottom fishing impacts is poorly known (Althaus et al. 2009). An understanding of cold-water coral life history traits, such as age, growth rates, and longevity, is essential to appreciate the nature and extent of these effects and to evaluate the time scale of recovery. Cold-water corals can attain ages on the order of decades to millennia (e.g. Druffel et al. 1995, Adkins et al. 2004, Andrews et al. 2009, Roark et al. 
2009). Some antipatharians or black corals are particularly long-lived, with estimated ages in the thousands of years. At the extreme end of longevity is an estimate exceeding $4000 \mathrm{yr}$ for a Leiopathes sp. colony in Hawaii (USA), representing the longestlived invertebrate to date (Roark et al. 2009).

The Azores harbor diverse cold-water coral garden communities, dominated by gorgonians, stylasterids, and black corals, predominantly inhabiting rocky hard-bottom areas in island slopes and seamounts (OSPAR Commission 2010a, Braga-Henriques et al. 2012, Tempera et al. 2012). Local artisanal fisheries have continually targeted some of these coral-rich areas in the seamounts for several decades, mostly using bottom-tending longline and handline gears. The bycatch of bottom longline fisheries revealed that Leiopathes sp. are often damaged and captured during fisheries operations (Sampaio et al. 2012), raising concerns on the extent of these impairments and their recovery potential.

The aim of the present study was to estimate age and growth rates of Leiopathes sp. in the Azores region using radiocarbon dating. Additional objectives were to (1) determine the variability in growth rates within and between black coral colonies from the same and different geographic regions; and (2) measure the correlation between colony age and skeletal axis diameter and height as a basis for bycatch census purposes and video transect analyses. Ultimately, the goal is to gather information to better evaluate the vulnerability of these species to fisheries impacts and the capacity of Leiopathes sp. for recovery from damage or removal.

\section{MATERIALS AND METHODS}

\section{Specimen collection and identification}

Black coral colonies were obtained from bycatch material from the local longline fishing fleet. Two specimens were collected from Condor seamount at depths of 293 and 366 m, 2 other from the Açor seamount at depths of 302 and $366 \mathrm{~m}$, and a fifth from the Voador seamount at a depth of $366 \mathrm{~m}$ (Fig. 1, Table 1). The material was deposited in the collection of the Department of Oceanography and Fisheries of the University of the Azores (DOP-UAz).

All colonies were identified as belonging to the genus Leiopathes (Family Leiopathidae) based on the presence of an irregular sympodial corallum with multi-directional branching and uniserial to biserial

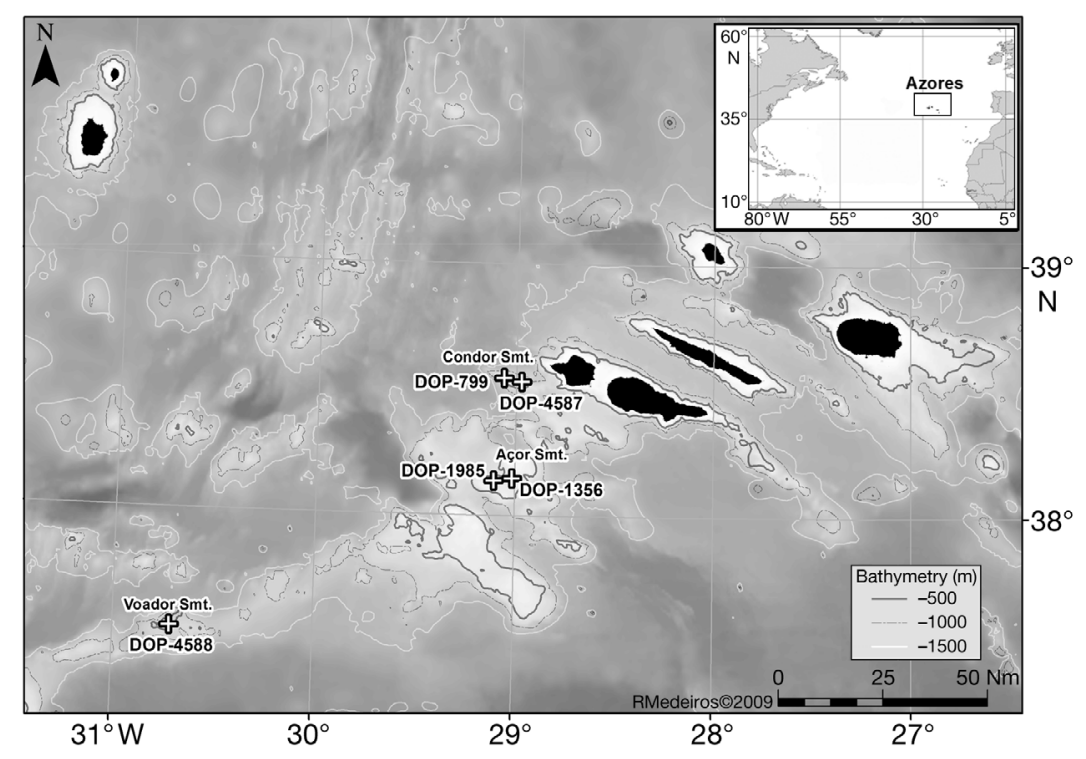

Fig. 1. Collection sites of Leiopathes sp. in the Condor (DOP-799, DOP-4587), Açor (DOP-1985, DOP-1356), and Voador (DOP-4588) seamounts, within the Azores region

Table 1. Leiopathes sp. Data of the 5 specimens used in this study. Collection year and site (bank) were known for all specimens, with the exception of DOP-1985, where collection year was estimated as 1985 by the fishermen. Axis diameter: minimum and maximum values at the sample extraction plane. Height: vertical colony height. ${ }^{a}$ : Collection year may not be representative of the final year of formation for this colony based on observation of encrusting organisms on exterior of basal portion. ${ }^{b}$ : Base axis was at an angle, making a diameter measurement difficult

\begin{tabular}{|c|c|c|c|c|c|c|c|}
\hline $\begin{array}{l}\text { Specimen } \\
\text { ID }\end{array}$ & Date & Site & Latitude, longitude & $\begin{array}{l}\text { Depth } \\
\text { (m) }\end{array}$ & $\begin{array}{l}\text { Axis diameter } \\
(\mathrm{mm})\end{array}$ & $\begin{array}{c}\text { Height } \\
\text { (cm) }\end{array}$ & Morphotype \\
\hline DOP-1985 & 1985 & Açor Bank & $38^{\circ} 17^{\prime} \mathrm{N}, 28^{\circ} 52^{\prime} \mathrm{W}$ & 366 & $28.9-33.1$ & 175 & 2 \\
\hline DOP-1356 & $23 \operatorname{Mar} 2007^{a}$ & Açor Bank & $38^{\circ} 17^{\prime} \mathrm{N}, 28^{\circ} 52^{\prime} \mathrm{W}$ & 307 & $16.5-17.8$ & 155 & 1 \\
\hline DOP-4588 & Jan 2009 & Voador Bank & $37^{\circ} 32^{\prime} \mathrm{N}, 30^{\circ} 43^{\prime} \mathrm{W}$ & 366 & $25-26^{b}$ & 137 & 1 \\
\hline DOP-799 & 17 Sep 2006 & Condor Bank & $38^{\circ} 08^{\prime} \mathrm{N}, 29^{\circ} 05^{\prime} \mathrm{W}$ & 293 & $11.4-14.2$ & 113 & 1 \\
\hline DOP-4587 & Jan 2009 & Condor Bank & $38^{\circ} 08^{\prime} \mathrm{N}, 29^{\circ} 05^{\prime} \mathrm{W}$ & 366 & $4.9-5.2$ & 43 & 3 \\
\hline
\end{tabular}


branchlets with a scorpioid arrangement. These branchlets bear small, simple, and smooth-surfaced spines reduced in size or absent on larger branches and stems (Opresko 1998). Careful examination of some of these morphological characters (e.g. gross morphology, size of the colony; length, diameter, and shape of the terminal branches, dimension and distribution of the spines and polyps on the axial skeleton) suggested that the studied specimens belonged to 3 morphotypes: (1) DOP-799, DOP-1356, DOP4588, (2) DOP-1985, and (3) DOP4587. Because the species currently classified under the genus Leiopathes in the NE Atlantic require revision (D. Opresko pers. comm.), we refrain from assigning these morphotypes to specific species. Genetic identification of these specimens was not possible due to the lack of freshly preserved material.

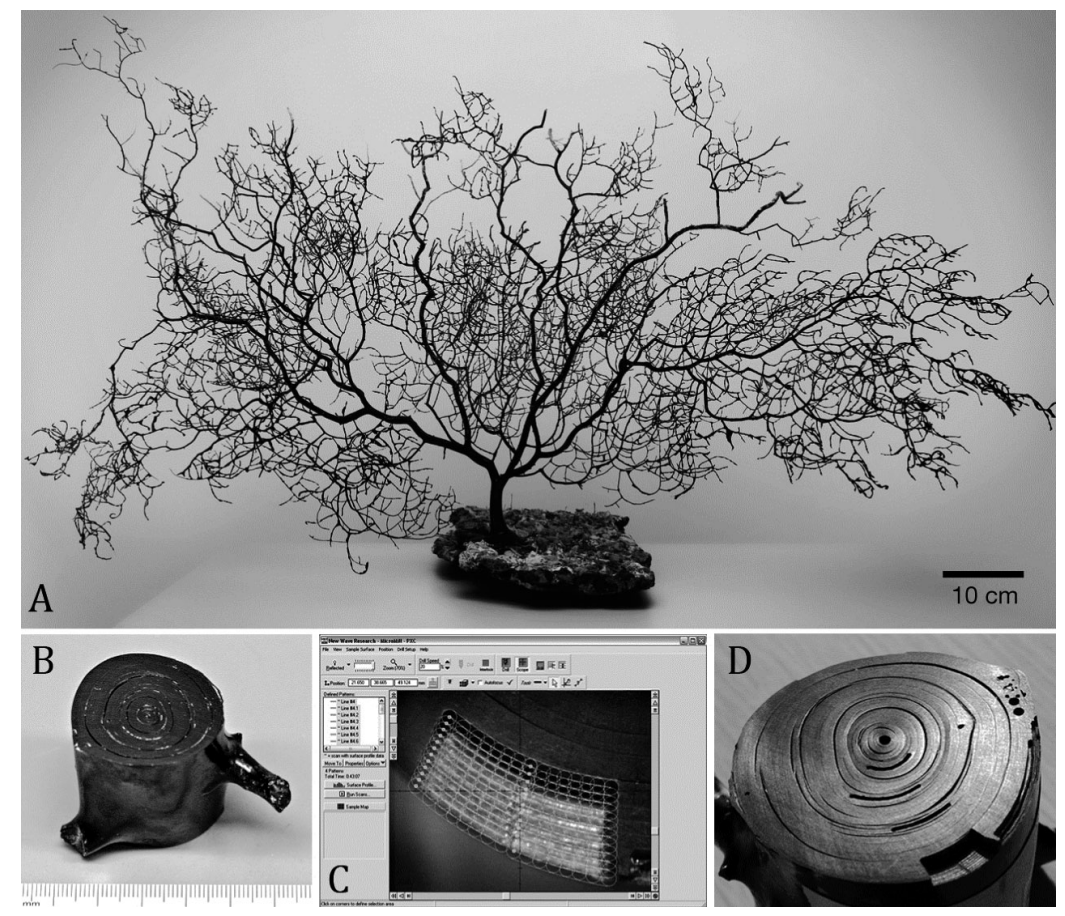

Fig. 2. Leiopathes sp. (A) Complete type-specimen (height: $62 \mathrm{~cm}$; axis diameter: $18 \mathrm{~mm}$ ) assigned to morphotype 3 (DOP reference collection). Estimated age is 300 to $1700 \mathrm{yr}$ based on the growth rates provided in this study. (B) Colony section used in sample extractions for DOP-1985. (C) Frame grab from micromill computer showing the sample series taken from the edge of DOP-1985, with an overlap of extraction paths ( $0.5 \mathrm{~mm}$ bit width). (D) Post-extraction surface of the coral section showing the narrower sample series at the edge, 3 intermediate radial samples (full bit width at $0.5 \mathrm{~mm}$ ), and the axial core extraction

Cross sections $1 \mathrm{~cm}$ thick were taken from the bases of the colonies with a hand saw (Fig. 2). The portions of each colony were examined to locate the best position for cross sectioning to optimize alignment of the skeletal axis with the vertical orientation of the micromilling machine (z-axis). A sample series of skeletal antipathin (a structural protein), oriented along the radius, was extracted using the micromilling machine for each colony section. Sample extraction began at the edge and progressed along radial lines successively toward the axial core. Each extraction was made with a $500 \mu \mathrm{m}$ carbide cutter bit with a spherical shape (Brasseler USA ${ }^{\circledR}$, Part No. H71.11.005). The bit was guided through the skeletal material at a depth near the bit radius $(\sim 250 \mu \mathrm{m})$, and multiple passes were made to obtain enough sample mass. Near-edge samples were $\sim 250 \mu \mathrm{m}$ in radial thickness because of overlapping extraction paths. Samples extracted closer to the core, and separated from the successive near-edge samples, had an extraction path thickness using the full bit diameter $(500 \mu \mathrm{m})$. Each extraction was removed successively with a fine-tipped blade under magnified viewing

conditions. Target extraction mass was near $3 \mathrm{mg}$ at a minimum for radiocarbon analyses. Because samples were extracted along radial lines, some extraction paths were full circle, sampling the entire radius, to increase sample mass for the period of formation. In order to obtain enough sample mass, core samples were typically $>500 \mu \mathrm{m}$ in diameter and deeper than the near-edge radial extraction.

The selection of sample areas within each colony depended on the size of the colony and the potential analysis, either radiocarbon dating or bomb radiocarbon dating. Rough estimates of age from growth zone counting and growth rates from other studies on similar corals (e.g. Roark et al. 2006) provided a basis for the limits of the extraction series (working to encompass pre-bomb to post-bomb $\Delta^{14} \mathrm{C}$ levels). For most colonies, the edge was sampled at the finer scale, stated previously, to evaluate the application of bomb radiocarbon dating. The locations of older samples ranging to the core were selected based on the regu- 
lar spacing and avoidance of fractures or separations in the skeletal structure. Pre-bomb samples from the fine scale series near the edge (determined later) and the older samples ranging to the core were used in radiocarbon dating. Extraction of coral material from the 5 coral colonies successfully produced $>50$ samples to provide a selection of measurement locations in each colony section. Samples were analyzed in successive sets, the results of which were used to make educated decisions for the next set of samples. Ultimately, 25 samples were selected and analyzed with sample mass ranging from 1.0 to $7.3 \mathrm{mg}$ and the number per colony ranging from 1 in the smallest colony to 10 in the largest colony (Table 2).

\section{Analytical measurements}

Extracted samples were submitted as powder to the Center for Accelerator Mass Spectrometry (CAMS) at Lawrence Livermore National Laboratories, Livermore, California, USA, for radiocarbon analysis. Sample $\mathrm{CO}_{2}$ was generated via combustion, converted to graphite and measured for radiocarbon $\left({ }^{14} \mathrm{C}\right)$ content using an accelerator mass spectrometer (AMS). The ${ }^{14} \mathrm{C}$ values were reported as $\Delta{ }^{14} \mathrm{C}$ (Stuiver \& Polach 1977) and were corrected for isotopic fractionation using measured $\delta^{13} \mathrm{C}$ values and an assumed $\delta^{13} \mathrm{C}$ value of $-17 \%$, rounded off from a mean of the measured values $(n=9,17.4 \pm 0.8 \% \mathrm{SD})$. For bomb radiocarbon dating, the $\Delta^{14} \mathrm{C}$ measured in the latest samples were used to determine rough estimates of age and growth from post-bomb to pre-bomb levels. For radiocarbon dating, the full series of pre-bomb $\Delta \Delta^{14} \mathrm{C}$ values were used to determine colony age, and were reported as conventional radiocarbon age (CRA) and calendar year before present (BP, relative to $1950 \mathrm{AD}$ ) corrected reservoir effects $(\Delta \mathrm{R})$. A calculated reservoir age of $399 \pm 17{ }^{14} \mathrm{C}$ yr was determined from a mean $\Delta{ }^{14} \mathrm{C}$ value of $-49 \pm 2 \%$ o $(n=9)$, reported for 1955 from the North Atlantic Ocean (Stuiver 1980), which was converted to the fraction modern (Fm) for 1950 (Fm = 0.9516), and then ${ }^{14} \mathrm{C}$ years with the following conversion $\left({ }^{14} \mathrm{C} y \mathrm{r}=-8033 \times \ln (\mathrm{Fm})\right)$. A global marine reservoir correction age of $464 \pm 23{ }^{14} \mathrm{C}$ yr (from the Marine09 supplementary material in Reimer et al. 2009)

Table 2. Leiopathes sp. Results from radiocarbon assays separated by colony (Specimen ID) and into the consecutive sample series taken along each radial axis (CAMS ID = Center for Accelerator Mass Spectrometry lab number and Sample ID = laboratory record). Provided are assumed $\left(-17 \%\right.$ ) and measured (given to $0.1 \%$ ) $\delta^{13} \mathrm{C}$ values, with the measured radiocarbon fraction modern $(\mathrm{Fm})$, calculated $\Delta^{14} \mathrm{C}$, and conventional radiocarbon age (CRA). >Modern: $>1950$ AD. ${ }^{a}$ : Samples combined to increase sample extraction mass

\begin{tabular}{|c|c|c|c|c|c|c|}
\hline Specimen ID & CAMS ID & Sample ID & $\delta^{13} \mathrm{C}(\%)$ & $\mathrm{Fm} \pm 1 \mathrm{SD}$ & $\Delta^{14} \mathrm{C} \pm 1 \mathrm{SD}(\%$ o) & $\mathrm{CRA} \pm 1 \mathrm{SD}(\mathrm{yr})$ \\
\hline DOP-1985 & $\begin{array}{l}147817 \\
147381 \\
147382 \\
147383 \\
147384 \\
147385 \\
147818 \\
147819 \\
147820 \\
147386\end{array}$ & $\begin{array}{l}\text { AA } 09 \\
\text { AA } 10 \\
\text { AA } 11 \\
\text { AA } 12 \\
\text { AA } 14 \\
\text { AA } 15 \\
\text { AA } 17 \\
\text { AA } 18 \\
\text { AA } 19 \\
\text { AA } 20\end{array}$ & $\begin{array}{c}-17 \\
-17 \\
-16.6 \\
-17 \\
-17 \\
-17 \\
-17 \\
-16.4 \\
-17 \\
-17\end{array}$ & $\begin{array}{l}0.9549 \pm 0.0035 \\
0.9509 \pm 0.0049 \\
0.9357 \pm 0.0028 \\
0.9330 \pm 0.0029 \\
0.9299 \pm 0.0031 \\
0.9241 \pm 0.0029 \\
0.9049 \pm 0.0040 \\
0.8705 \pm 0.0036 \\
0.7862 \pm 0.0030 \\
0.7283 \pm 0.0025\end{array}$ & $\begin{array}{r}-52.0 \pm 3.5 \\
-55.9 \pm 4.9 \\
-71.1 \pm 2.8 \\
-73.8 \pm 2.9 \\
-76.8 \pm 3.1 \\
-82.6 \pm 2.9 \\
-101.6 \pm 4.0 \\
-135.8 \pm 3.6 \\
-219.5 \pm 3.0 \\
-277.0 \pm 2.5\end{array}$ & $\begin{array}{r}370 \pm 30 \\
405 \pm 45 \\
535 \pm 25 \\
555 \pm 30 \\
585 \pm 30 \\
635 \pm 25 \\
800 \pm 40 \\
1115 \pm 35 \\
1935 \pm 35 \\
2545 \pm 30\end{array}$ \\
\hline DOP-1356 & $\begin{array}{l}147824 \\
147825 \\
147829 \\
147830 \\
147823\end{array}$ & $\begin{array}{l}\text { AA } 44 \\
\text { AA } 46 \\
\text { AA } 45 \\
\text { AA } 47 \\
\text { AA } 43\end{array}$ & $\begin{array}{c}-17.6 \\
-17 \\
-17.4 \\
-17.2 \\
-17\end{array}$ & $\begin{array}{l}0.9520 \pm 0.0028 \\
0.9445 \pm 0.0033 \\
0.9387 \pm 0.0034 \\
0.9354 \pm 0.0027 \\
0.9259 \pm 0.0030\end{array}$ & $\begin{array}{l}-54.9 \pm 2.8 \\
-62.4 \pm 3.3 \\
-68.1 \pm 3.4 \\
-71.3 \pm 2.7 \\
-80.8 \pm 3.0\end{array}$ & $\begin{array}{l}395 \pm 25 \\
460 \pm 30 \\
510 \pm 30 \\
535 \pm 25 \\
620 \pm 30\end{array}$ \\
\hline DOP-4588 & $\begin{array}{l}147826 \\
147831 \\
147821 \\
147827 \\
147387\end{array}$ & $\begin{array}{c}\text { AA } 21+22^{\mathrm{a}} \\
\text { AA } 23 \\
\text { AA } 33 \\
\text { AA } 34 \\
\text { AA } 35\end{array}$ & $\begin{array}{c}-18.9 \\
-17 \\
-16.6 \\
-18.1 \\
-17\end{array}$ & $\begin{array}{l}1.0945 \pm 0.0036 \\
1.1006 \pm 0.0034 \\
0.9303 \pm 0.0039 \\
0.9196 \pm 0.0028 \\
0.9046 \pm 0.0028\end{array}$ & $\begin{array}{r}86.6 \pm 3.6 \\
92.7 \pm 3.4 \\
-76.4 \pm 3.9 \\
-87.0 \pm 2.8 \\
-102.0 \pm 2.8\end{array}$ & $\begin{array}{l}>\text { Modern } \\
>\text { Modern } \\
580 \pm 35 \\
675 \pm 25 \\
805 \pm 30\end{array}$ \\
\hline DOP-799 & $\begin{array}{l}147388 \\
147828 \\
147822 \\
147389\end{array}$ & $\begin{array}{l}\text { AA } 37 \\
\text { AA } 40 \\
\text { AA } 36 \\
\text { AA } 39\end{array}$ & $\begin{array}{c}-17 \\
-18.2 \\
-17 \\
-17\end{array}$ & $\begin{array}{l}1.1040 \pm 0.0142 \\
0.9562 \pm 0.0033 \\
0.9459 \pm 0.0035 \\
0.9372 \pm 0.0030\end{array}$ & $\begin{aligned} 96.0 & \pm 14.2 \\
-50.7 & \pm 3.3 \\
-61.0 & \pm 3.5 \\
-69.5 & \pm 3.0\end{aligned}$ & $\begin{array}{l}>\text { Modern } \\
360 \pm 30 \\
445 \pm 35 \\
520 \pm 30\end{array}$ \\
\hline DOP-4587 & 147390 & AA 42 & -17 & $0.9323 \pm 0.0041$ & $-74.4 \pm 4.1$ & $565 \pm 40$ \\
\hline
\end{tabular}


was subtracted from the reservoir age $\left(399 \pm 17{ }^{14} \mathrm{C}\right.$ yr) for a $\Delta \mathrm{R}$ value of $-65 \pm 29{ }^{14} \mathrm{C}$ yr. The negative result is consistent with more centrally located ocean positions, such as Hawaii $\left(\Delta \mathrm{R}=-28 \pm 4{ }^{14} \mathrm{C}\right.$ yr; Roark et al. 2006; cf. coastal regions affected by upwelling with positive $\Delta \mathrm{R}$ values, e.g. Sherwood et al. 2008, Soares \& Martins 2010). Calibrated calendar age was determined using the calculated $\Delta \mathrm{R}$ value in Calib 6.0 (http://calib.qub.ac.uk) with the Marine09 calibration record (Reimer et al. 2009). Because the sample extraction was composed of material formed over several decades of deposition, the Calib 6.0 calculation option of a 'sample calendar year span' was chosen in the Calib 6.0 analysis (Stuiver \& Reimer 1993). This option performs a moving average of the calibration curve and is the best option for this kind of sample design, and the final reported age for each sample was the median probability age. Final sample age determinations were corrected to the time of collection by adding 35 to $59 \mathrm{yr}$, depending on the sample. Based on these age data, long-term average growth rates for full colonies and within colonies were determined and plotted for interpretation.

\section{RESULTS}

\section{Radiocarbon age}

Fm measured for ${ }^{14} \mathrm{C}$ ranged, as expected, from a low ratio in the core of the largest colony to $>1.0$ (>Modern) for the most recent and post-bomb affected samples near or at the edge of 2 of the 5 colonies (Table 2). Calculated $\Delta{ }^{14} \mathrm{C}$ values ranged from a low of $-277.0 \pm 2.5 \%$ o (mean $\pm \mathrm{SD}$ ) from the core of DOP1985 to post-bomb elevated values approaching $100 \%$ in the near-edge material of DOP-799 and DOP-4587. Change in $\Delta^{14} \mathrm{C}$ across the radial transects of each colony revealed a variable rate of decline with 3 of the 5 colonies having similar rates of decline (Fig. 3). This corresponded to conventional radiocarbon ages ranging from near 500 to $600{ }^{14} \mathrm{C}$ yr for the smallest colonies to $>2000{ }^{14} \mathrm{C}$ yr for the largest colony.

The age of individual extracted samples and total colony age (lifespan of the colony) were determined using the calibrated radiocarbon ages (Table 3 ). Only measured $\Delta^{14} \mathrm{C}$ values less than the value used to determine a $\Delta \mathrm{R}$ could be used in determining a calendar year before 1950; hence, some pre-bomb values were deemed 'Modern' and likely formed close to 1950, but were not used in the determination of sample age. The age of the 2 smallest colonies was near $300 \mathrm{yr}$, and the oldest was $\sim 2320$ yr old. Dis- tances to the center of the extraction path (cut width) were plotted with radiocarbon age to reveal differences and similarities in growth rates over time, both within and between colonies (Fig. 4).

\section{Growth rates}

Growth rates differed among the Leiopathes sp. specimens studied. The smallest and largest colonies had similar growth rates of 5 to $7 \mu \mathrm{m} \mathrm{yr}^{-1}$, whereas the other 3 colonies grew more rapidly by 3 to 5 times, with growth rates of $\sim 20$ to $30 \mu \mathrm{m} \mathrm{yr}^{-1}$ (Table 4 ). The largest colony was the slowest-growing overall, but the within-colony rates differed over time (Fig. 5). The earliest and latest growth rates were similar at 4

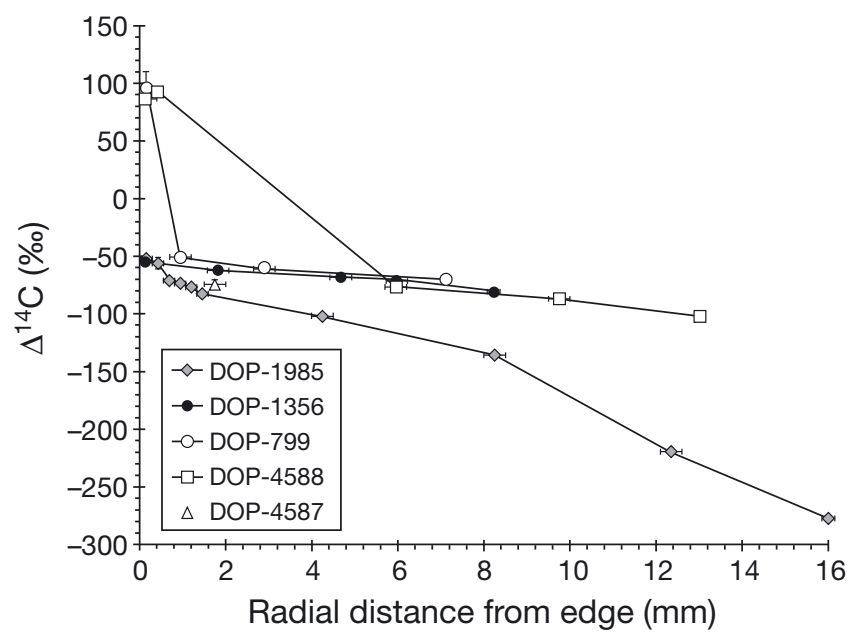

Fig. 3. Leiopathes sp. Radial distance from axis to outer edge (mm) versus $\Delta^{14} \mathrm{C}$ determinations for the 5 colonies studied

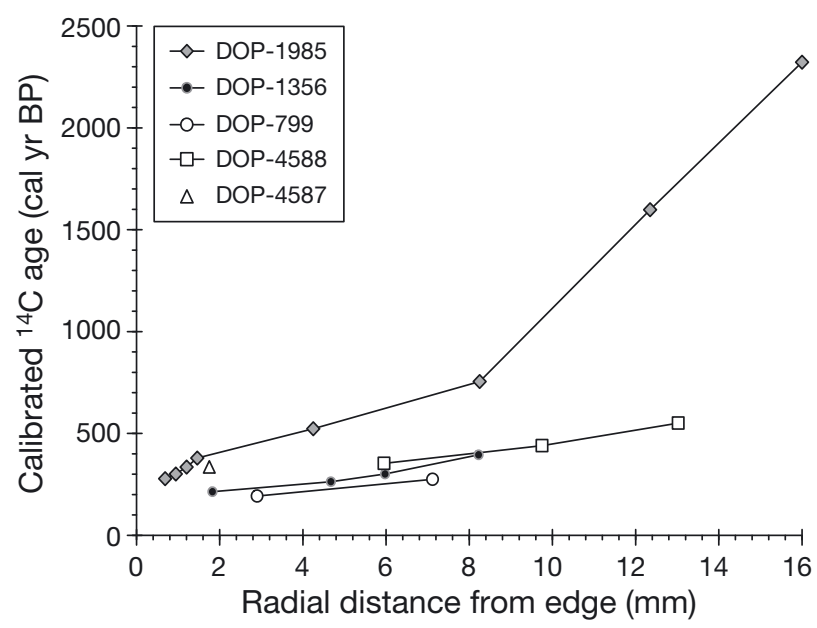

Fig. 4. Leiopathes sp. Radial distance from axis to outer edge versus reservoir-corrected calendar age for the 5 colonies studied 
Table 3. Leiopathes sp. Synopsis of radial samples extracted from the coral axis, given as the distance from the section edge toward the center (distance to the center of extraction width for mean growth zone radius), with the width of the cut from milling based on the bit diameter and extraction (successive radial path or single path using full tip diameter). Listed are the calculated calendar years before present $(\mathrm{BP} ;$ median probability age) with the uncertainty from Calib 6.0 (moving average) with a reservoir age $(\Delta \mathrm{R})$ of $-65 \pm 29$ yr (ca. $\Delta^{14} \mathrm{C}=-49 \pm 2$; Stuiver 1980 ; mean $\pm \mathrm{SD}$ ). Age was corrected to time of collection from the calibration year of 1950. Data in parentheses are $1 \mathrm{SD}$ calibrated age ranges. >Modern: $>1950 \mathrm{AD} .{ }^{a}: \Delta^{14} \mathrm{C}$ value too close to the pre-bomb reference used in determining $\Delta \mathrm{R}$, which leads to an error in Calib 6.0 age calculations

\begin{tabular}{|c|c|c|c|c|c|}
\hline $\begin{array}{l}\text { Specimen } \\
\text { ID }\end{array}$ & $\begin{array}{l}\text { Sample } \\
\text { ID }\end{array}$ & $\begin{array}{l}\text { Distance } \\
\text { (mm) }\end{array}$ & $\begin{array}{l}\text { Cut width } \\
\text { (mm) }\end{array}$ & $\begin{array}{l}\text { Calendar } \\
\text { years BP }\end{array}$ & $\begin{array}{l}\text { Age } \\
(\mathrm{yr})\end{array}$ \\
\hline \multirow[t]{10}{*}{ DOP-1985 } & AA 09 & 0.15 & 0.30 & Modern & Modern \\
\hline & AA 10 & 0.43 & 0.26 & $95(5-135)$ & $130(40-170)$ \\
\hline & AA 11 & 0.69 & 0.26 & 245 (195-295) & $280(230-330)$ \\
\hline & AA 12 & 0.95 & 0.26 & $265(215-320)$ & $300(250-355)$ \\
\hline & AA 14 & 1.20 & 0.26 & $300(255-350)$ & $335(290-385)$ \\
\hline & AA 15 & 1.46 & 0.26 & $345(300-390)$ & $380(330-425)$ \\
\hline & AA 17 & 4.25 & 0.50 & $490(450-525)$ & $525(485-560)$ \\
\hline & AA 18 & 8.25 & 0.50 & $720(675-765)$ & $755(710-800)$ \\
\hline & AA 19 & 12.35 & 0.50 & $1560(1500-1620)$ & $1600(1540-1660)$ \\
\hline & AA 20 & 16.00 & 0.30 & $2290(2230-2340)$ & $2320(2270-2380)$ \\
\hline \multirow[t]{5}{*}{ DOP-1356 } & AA 44 & 0.15 & 0.30 & $74(0-100)$ & $130(60-160)$ \\
\hline & AA 46 & 1.83 & 0.50 & $160(105-240)$ & $215(160-300)$ \\
\hline & AA 45 & 4.68 & 0.50 & $205(180-270)$ & 265 (235-325) \\
\hline & AA 47 & 5.98 & 0.50 & 245 (195-290) & $300(250-350)$ \\
\hline & AA 43 & 8.23 & 0.30 & $340(285-380)$ & $395(340-440)$ \\
\hline \multirow[t]{5}{*}{ DOP-4588 } & AA $21+22$ & 0.28 & 0.28 & >Modern & - \\
\hline & AA 23 & 0.70 & 0.14 & >Modern & - \\
\hline & AA 33 & 5.95 & 0.50 & $295(250-355)$ & 355 (305-415) \\
\hline & AA 34 & 9.75 & 0.50 & $380(330-430)$ & $440(385-485)$ \\
\hline & AA 35 & 13.03 & 0.30 & $490(465-520)$ & $550(520-580)$ \\
\hline \multirow[t]{4}{*}{ DOP-799 } & AA 37 & 0.15 & 0.30 & >Modern & - \\
\hline & AA 40 & 0.95 & 0.50 & Modern $^{a}$ & - \\
\hline & AA 36 & 2.90 & 0.50 & $135(75-230)$ & 195 (130-285) \\
\hline & AA 39 & 7.12 & 0.26 & $220(185-275)$ & $275(240-335)$ \\
\hline DOP-4587 & AA 42 & 1.75 & 0.50 & $275(220-340)$ & 335 (280-395) \\
\hline
\end{tabular}

to $5 \mu \mathrm{m} \mathrm{yr}^{-1}$, with a period of more rapid growth at $\sim 20 \mu \mathrm{m} \mathrm{yr}^{-1}$ through the upper middle ages of the colony ( 2 to $8 \mathrm{~mm}$ in radius and $\sim 400$ to 750 yr ago). In addition, growth rates of the other 3 colonies were consistent with the faster growth period of the largest colony. Colony ages across the 5 specimens used in this study did not significantly correlate with the main axis diameter of the colony $(\mathrm{r}=0.76, \mathrm{p}=$ $0.14, \mathrm{n}=5)$ or their height $(\mathrm{r}=$ 0.59, $\mathrm{p}=0.29, \mathrm{n}=5$ ), meaning that axis diameter and colony height did not increase linearly with colony age based on our limited number of samples.

Use of bomb radiocarbon dating provided estimates of age and growth that support the conventional radiocarbon dating, but the findings were not well defined. Because of low growth rates and the relatively short time frame for bomb radiocarbon dating ( $\sim 50 \mathrm{yr})$, there was not enough material for good temporal resolution. Based on changes in $\Delta^{14} \mathrm{C}$ from what can be classified as pre-bomb to postbomb values near the edge of the coral section, 2 colonies provided estimates of age. For DOP-799, the assumption was made that sample extraction was before and

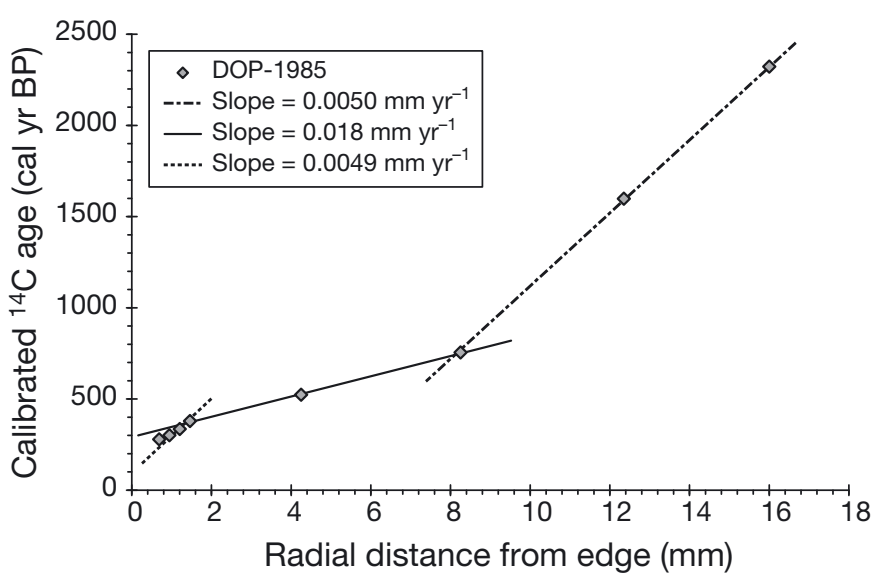

Fig. 5. Leiopathes sp. Radial distance from axis to outer edge versus reservoir-corrected calendar age for the largest colony studied (DOP-1985), with variable growth rates near the initial rise of bomb $\Delta^{14} \mathrm{C}$ and a limit of calendar year 1955 was chosen. Support for this determination comes from the measured value of $-50.7 \pm 3.3 \%$, similar to the value (mean \pm SD) determined for the North Atlantic Ocean pre-bomb levels (-49 $\pm 2 \%$; Stuiver 1980). A conservative growth rate estimate based on the extremes of extraction radius provided a rate of $\sim 10$ to $20 \mu \mathrm{m} \mathrm{yr}{ }^{-1}$. For DOP-4588, it was assumed that the second sample measurement $(92.7 \pm$ $3.4 \%$ ) encompassed the rise and peak for bomb $\Delta^{14} \mathrm{C}$. Given that the sample crossed the peak years, 1965 was arbitrarily chosen as the year of formation. A conservative growth rate estimate was approximately 10 to $25 \mu \mathrm{m} \mathrm{yr}^{-1}$. Bomb radiocarbon dating estimates for 2 of the other 3 colonies was not possible because elevated levels were not measured due to other factors (edge not sampled or no post-bomb growth). 
Table 4. Leiopathes sp. Mean colony growth rates based on the maximum age estimate. Mean radius and radius range were determined to account for radial growth variation. ${ }^{a}$ : Estimated last year of formation at 1950 leads to a calculated growth rate of 0.024 (0.021-0.030) $\mathrm{mm} \mathrm{yr}^{-1}$ (consideration for evidence that no post-bomb growth occurred)

\begin{tabular}{|c|c|c|c|c|c|}
\hline $\begin{array}{l}\text { Specimen } \\
\text { ID }\end{array}$ & $\begin{array}{l}\text { Maximum age } \\
(\mathrm{yr})\end{array}$ & $\begin{array}{l}\text { Mean radius } \\
(\mathrm{mm})\end{array}$ & $\begin{array}{l}\text { Radius range } \\
(\mathrm{mm})\end{array}$ & $\begin{array}{l}\text { Mean growth rate } \\
\left(\mathrm{mm} \mathrm{yr}^{-1}\right)\end{array}$ & $\begin{array}{c}\text { Growth rate range } \\
\qquad\left(\mathrm{mm} \mathrm{yr}^{-1}\right)\end{array}$ \\
\hline DOP-1985 & $2320(2270-2380)$ & 16.00 & $15.60-16.40$ & 0.0069 & $0.0066-0.0072$ \\
\hline DOP-1356 & 395 (340-440) & 8.23 & $7.95-8.50$ & $0.021^{\mathrm{a}}$ & $0.018-0.025^{\mathrm{a}}$ \\
\hline DOP-4588 & $550(520-580)$ & 13.03 & $12.97-13.07$ & 0.024 & $0.022-0.025$ \\
\hline DOP-799 & 275 (240-335) & 7.12 & $6.17-8.07$ & 0.026 & $0.018-0.033$ \\
\hline DOP-4587 & 335 (280-395) & 1.75 & $1.55-1.95$ & 0.0052 & $0.0039-0.0070$ \\
\hline
\end{tabular}

\section{DISCUSSION}

\section{Radiocarbon dating}

Radiocarbon dating indicated that some Leiopathes sp. black corals in the Azores have been continuously growing for at least $2300 \mathrm{yr}$ with growth rates as low as $5 \mu \mathrm{m} \mathrm{yr}^{-1}$. These findings corroborate previous reports of high longevity and slow growth rates for Leiopathes sp. in the Pacific and NW Atlantic (Roark et al. 2006, 2009, Williams at al. 2006, Prouty et al. 2011), demonstrating that these life history traits are consistent across oceanographic regions of the world.

Our age estimates for Leiopathes sp. fall within the lower to middle range of reported values for other Leiopathes sp. studies (198 to 4265 yr: Roark et al. 2006, 2009, Williams et al. 2006, Prouty et al. 2011). However, the maximum age reported here was not from the tallest and thickest colony recorded from the region, suggesting that Leiopathes sp. in the Azores may attain ages exceeding this estimate. A large specimen that was collected from Condor Seamount had a height of $3 \mathrm{~m}$ and an axis diameter of $40 \mathrm{~mm}$. Unfortunately, this specimen belonged to a private collection and we were unable to sample it for radiocarbon dating. However, 1 of the goals of this study was to estimate age for colonies in the field from axis diameter. Although correlation between age estimates and axis diameter resulted in a wide range of uncertainty, an age interval for this specimen was calculated using the range of growth rates of the largest colony aged in this study (DOP-1985; 6.6 to $7.2 \mu \mathrm{m} \mathrm{yr}^{-1}$ radial growth rate). Assuming the observed changes in growth rate over the lifespan would be similar for a colony of this size, an estimate of 2800 to 3000 yr was determined. Given the full range of measured radial growth rates in this study (5.2 to $26.0 \mu \mathrm{m} \mathrm{yr}^{-1}$ ), age could be between 700 and 3900 yr. However, it is likely that a mean growth rate is most applicable to a colony this large and an age near $3000 \mathrm{yr}$ is likely. According to this estimation the theoretical maximum age of Leiopathes sp. in the Azores is similar to the maximum age reported for Leiopathes sp. in Hawaii.

Growth rates of our samples were comparable to those reported for the Gulf of Mexico (8 to $22 \mu \mathrm{m} \mathrm{yr}^{-1}$ : Prouty et al. 2011), but greater than those given for Hawaii (2 to $13 \mu \mathrm{m} \mathrm{yr}^{-1}$ : Roark et al. 2006, 2009). The reasons for these differences are uncertain, but may be related to factors such as food availability discussed in more detail in the next section. Despite these differences, growth rates in Leiopathes sp. are generally lower and lifespans greater than in other deep-sea coral species. For example, the deep-sea antipatharian species Stauropathes arctica off Newfoundland (Canada) grows faster and has a shorter lifespan than Leiopathes sp. (growth rate $=33$ to $66 \mu \mathrm{m} \mathrm{yr}^{-1}$, maximum reported lifespan $=82 \mathrm{yr}$ : Sherwood \& Edinger 2009). Octocorals in general have more rapid growth rates and lower lifespans than Leiopathes sp., with growth rates between 50 and

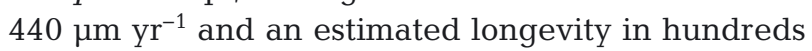
of years (Andrews et al. 2002, Sherwood et al. 2006, Watling et al. 2011). The only other species with comparable growth and longevity to Leiopathes sp. is the zoanthid Gerardia sp. (lifespan in the order of millennia with growth rates as low as $5 \mu \mathrm{m} \mathrm{yr}^{-1}$ : Druffel et al. 1995, Parrish \& Roark 2009, Roark et al. 2009).

\section{Variability in growth rates}

We estimated age and growth rates of 5 Leiopathes sp. colonies of different sizes to explore whether variations in age and growth were related to colony size. Growth rates differed among the colonies, with the largest and smallest colonies presenting the slowest

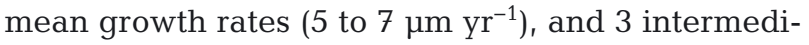
ate sized colonies presenting 4 to 5 times higher mean growth rates (21 to $26 \mu \mathrm{m} \mathrm{yr}^{-1}$ ). This may be related to differences in colony size, colony collection site, or species-specific differences. 
The morphological characters of the coral colonies indicated 3 distinct morphotypes. The largest, the smallest, and the 3 intermediate sized colonies represented 1 morphotype each. Because the species classified under the genus Leiopathes in the NE Atlantic require revision (D. Opresko pers. comm.), and we did not have enough freshly preserved material for genetic identification, we were unable to determine whether the 3 morphotypes were different species. Recent molecular phylogenetic studies on deep-sea bamboo corals have demonstrated high lability in morphological characters traditionally used for their classification (Dueñas \& Sanchez 2009) i.e. deep-sea corals may show considerable phenotypic plasticity within species.

If the 3 morphotypes correspond to different species, then the observed differences in growth rates may correspond to species-specific rates. Considerable growth rate differences have been reported for closely related antipatharian species of the genus Antipathes (Roark et al. 2006, Love at al. 2007). Growth rates of $A$. dichotoma from $50 \mathrm{~m}$ depth off Hawaii (Roark et al. 2006) were up to 8 times greater than growth rates reported for $A$. dendrochristos collected at $106 \mathrm{~m}$ depth off southern California (Love et al. 2007).

Alternatively, different growth rates may reflect differences in food availability around the seamount. The differences in growth rates were recorded for specimens collected within the Açor (DOP-1985, DOP-1356) and Condor Seamounts (DOP-799, DOP4587, Table 4). Isotopic evidence indicates that antipatharian corals feed on suspended matter derived from surface production (Roark et al. 2006, 2009, Sherwood et al. 2008), which can be influenced by local hydrographic patterns. In the Azores, information on near-bottom oceanographic conditions (currents, temperatures, and biogeochemical parameters) is scarce and regional models provide only coarse information; however, there is evidence that current circulation and local upwelling-downwelling patterns around seamounts are distinct from the surrounding ocean in the Northeast Atlantic Ocean, producing a diverse and complex physical environment (Vilas et al. 2009, Mendonça et al. 2012). Preliminary data on particulate organic carbon (POC) influx for Condor Seamount suggest that POC concentrations can be nearly 2 orders of magnitude greater on the northern slope relative to the southern slope (A. Colaço pers. comm.). This spatial heterogeneity in particle flux at the microhabitat scale could explain differences observed in coral growth rates on a seamount. Large intra-seamount variability in POC concentrations and plankton biomass has also been recorded at the Sedlo and Seine Seamounts located in subtropical waters of the northeast Atlantic Ocean, related to differences in local circulation around the seamount (Vilas et al. 2009).

Growth rate comparisons of Leiopathes from different oceanographic regions suggest that surface-layer productivity, and thus food availability, may influence coral growth rates. We measured, rates similar to those reported for the Gulf of Mexico, and greater than those calculated for Hawaii. Primary productivity estimates in the Azores region (385 $\mathrm{mg} \mathrm{C} \mathrm{m}^{-2} \mathrm{~d}^{-1}$ ) are similar to the Gulf of Mexico (417 $\mathrm{mg} \mathrm{C} \mathrm{m}^{-2} \mathrm{~d}^{-1}$ ), but are nearly 2 times greater than for the Hawaii region (228 $\mathrm{mg} \mathrm{C} \mathrm{m}^{-2} \mathrm{~d}^{-1}$, www.seaaroundus.org), reflecting similarities in the trends observed for Leiopathes growth rates among these regions. Regional differences in growth rates of bamboo coral in New Zealand have also been attributed to differences in oceanographic conditions and food availability (Tracey et al. 2007).

A third potential explanation relates to variations in growth rates throughout the life span of the coral, rather than to species-specific growth rates. Roark et al. (2006) found greater radial growth rates over the initial $400 \mathrm{yr}$ of a $2370 \mathrm{yr}$ old Leiopathes sp. from Hawaii. More recently, Prouty et al. (2011) reported an inverse relationship between colony age and growth rates based on measurements in 5 colonies with different axis diameters. Our results show a contrasting pattern, with lowest growth rates (4 to $5 \mu \mathrm{m}$ $\mathrm{yr}^{-1}$ ) recorded over the initial $1600 \mathrm{yr}$ and the last 300 yr of lifespan of the $2320 \mathrm{yr}$ old Leiopathes sp., with a period of more rapid growth $\left(20 \mu \mathrm{m} \mathrm{yr}^{-1}\right)$ during the intermediate $400 \mathrm{yr}$ of life. Similar growth rates were recorded for our smallest specimen with a lifespan of 300 yr. These results suggest low growth rates in young and old colonies. Low initial growth rates could be related to low surface area exposed to the currents delivering organic particles on which the polyps are feeding, thus capturing only few resources for growth, as suggested for bamboo corals from the Gulf of Alaska (Roark et al. 2005). In this scenario, the growth rate would increase as the coral surface area and feeding efficiency increased, but may slow down as the colony reaches a maximum size. Studies on the growth and modularity of colonial cnidarians suggest that growth rates and colony maximum sizes are controlled by size-dependent interactions between the colony and the environment, such as the balance between metabolic rate and resource capture (e.g. Sebens 1982, Kim \& Lasker 1998). As the size of the colony increases, the 
amount of resources captured by different parts of the colony are reduced by colony self-shading. In addition, energy allocation to reproduction and other physiological functions may be favored in relation to growth (Kim \& Lasker 1998).

An additional consideration with the observed growth rate variability is the reliance of radiocarbon dating on the stability of the ${ }^{14} \mathrm{C}$ reference record over time. It is important to note that a series of assumptions are necessary in this instance because time-specific radiocarbon records, extending back $2000 \mathrm{yr}$, do not exist as a reference in the region. It is assumed that the calculated $\Delta \mathrm{R}$ value for the mixed layer is relatively consistent over time, but minor variations due to upwelled dissolved inorganic carbon or POC (depending on the primary source for skeletal growth) could change the reservoir age for unknown periods of time. A minor depression of $\Delta^{14} \mathrm{C}$ on the order of $10 \%$ can lead to a positive change in reservoir age of $85{ }^{14} \mathrm{C}$ yr for this study. This factor was described for the northeast Atlantic from historical samples, primarily from the ocean margin, and was attributed to the North Atlantic Oscillation (Tisnérat-Laborde et al. 2010). A problem with age estimates determined in this study is unlikely because (1) sample extraction covered decades of growth and likely normalizes such minor variations $(>10 \mathrm{yr}$ period) and (2) the Azores are more closely associated with the structural stability of the North Atlantic Gyre; nevertheless, it is important to mention this potential complication when making age determinations on deep-sea corals.

\section{Management and conservation}

As is the case with old-growth forests of terrestrial environments, our findings indicate that Leiopathes are particularly vulnerable to natural and anthropogenic disturbance. Once removed, these colonial organisms will not return to their former structural and ecological significance within our lifetime. Disturbance and removal from bottom trawling is among the most significant threats to cold-water corals (Althaus et al. 2009), and recent studies have demonstrated that other bottom-set fishing gears, such as longlines, can also significantly impact these communities in areas of intense fishing (Duran Muñoz et al. 2011, Sampaio et al. 2012). In the Azores, bottom trawling and deep-sea netting are forbidden and only bottom long lining is allowed (European Council Regulation [EC] No. 1568/2005 of 20 September 2005; see also Probert et al. 2007, Santos et al. 2009).
Recent studies on bycatch during longline fishing experiments revealed that $33 \%$ was composed of corals, and $\sim 7 \%$ of the corals caught were antipatharians (DOP-UAz unpublished data).

Anecdotal reports from fishermen suggest a progressive reduction in the accidental capture of Leiopathes after $20 \mathrm{yr}$ of bottom-longline fishing on insular slopes and seamounts. Large Leiopathes colonies ( $>2 \mathrm{~m}$ tall), and previously collected by fishermen, were not recorded in video surveys recently conducted in the Azores (A. Braga-Henriques pers. obs.). This finding could indicate that the largest and oldest colonies have already been removed from the population in heavily fished areas. These observations suggest that bottom longlines have had a destructive effect, and management strategies to reduce impacts to these ancient corals should be implemented.

The Government of the Azores recently created 4 deep-sea marine protected areas for the conservation of particularly sensitive benthic habitats, such as coral and sponge reefs and gardens. These protected areas are the Sedlo Seamount (Santos et al. 2009, 2010), and 3 high seas areas claimed by Portugal to the Commission on the Limits of the Continental Shelf (Altair and Antialtair Seamounts, and an area of the Mid-Atlantic Ridge north of the Azores), of which all are part of the OSPAR network of Marine Protected Areas (OSPAR Commission 2010b). The present study on Leiopathes contributes to this conservation effort by providing estimates of growth and longevity for an important structural member of these habitats, one of the longest-lived corals known. This information must be considered for the classification of additional vulnerable habitats that harbor ancient communities and deserve protection.

Acknowledgements. IMAR-DOP/UAz (Research and Development Unit no. 531) and LarSyS-Associated Laboratory are supported by the Portuguese Foundation for Science and Technology (FCT) under a strategic project and DRCTC-GR Azores through a Pluriannual Funding scheme. This study was supported by the EU-funded CoralFISH project, Marie Curie International Reintegration Grant (to M.C.-S., PIRG03-GA-2008-231109), post-doctoral fellowship from FCT (to M.C.-S., SFRH-BPD-34634-2007), and a PhD scholarship from Direcção Regional para a Ciência e a Tecnologia (to A.B.-H., M3.1.2/F/016/2008). The service charges for this open access publication have been covered by LARSyS Associated Laboratory through FCT/MCE project PEst-OE/ EEI/LA0009/2011. We thank bottom long-line fishermen, in particular J. Gonçalves, for providing specimens. P. Reimer (Queen's University, Belfast), E. Druffel (University of California, Irvine), O. Sherwood (Dolan Integration Group), and T. Brown (Lawrence Livermore National Laboratory) are 
thanked for insight and assistance with radiocarbon data analyses and the determination of an appropriate $\Delta \mathrm{R}$ value for the region. Samples were extracted with the infrastructural support of Moss Landing Marine Laboratories, and radiocarbon processing via accelerator mass spectrometry was performed by T. Brown at the Center for Accelerator Mass Spectrometry (LLNL). The map was produced by R. Medeiros at DOP-UAc. We thank F. Parrish and R. Nichols of NOAA Fisheries for a manuscript review.

\section{LITERATURE CITED}

Adkins JF, Henderson GM, Wang SL, O'Shea S, Mokadem F (2004) Growth rates of the deep-sea scleractinia Desmophyllum cristagalli and Enallopsammia rostrata. Earth Planet Sci Lett 227:481-490

Althaus F, Williams A, Schlacher TA, Kloser RJ and others (2009) Impacts of bottom trawling on deep-coral ecosystems of seamounts are long-lasting. Mar Ecol Prog Ser 397:279-294

> Andrews AH, Cordes E, Mahoney MM, Munk K, Coale KH, Cailliet GM, Heifetz J (2002) Age and growth and radiometric age validation of a deep-sea, habitat-forming gorgonian (Primnoa resedaeformis) from the Gulf of Alaska. Hydrobiologia 471:101-110

> Andrews AH, Stone RP, Lundstrom CC, DeVogelaere AP (2009) Growth rate and age determination of bamboo corals from the northeastern Pacific Ocean using refined ${ }^{210} \mathrm{~Pb}$ dating. Mar Ecol Prog Ser 397:173-185

Braga-Henriques A, Carreiro-Silva M, Tempera F, Porteiro FM and others (2012) Carrying behavior in the deep-sea crab Paromola cuvieri (Northeast Atlantic). Mar Biodivers 42:37-46

> Clark MR, Rowden AA (2009) Effects of deepwater trawling on the macro-invertebrate assemblages of seamounts on the Chatham Rise, New Zealand. Deep-Sea Res I 56: 1540-1554

Costello MJ, McCrea M, Freiwald A, Lundalv T and others (2005) Role of cold-water Lophelia pertusa coral reefs as habitat in the NE Atlantic. In: Freiwald A, Roberts JM (eds) Cold-water corals and ecosystems. Springer-Verlag, Berlin, p 771-805

Druffel ERM, Griffin S, Witter A, Nelson E, Southon J, Kashgarian M, Vogel J (1995) Gerardia: bristlecone pine of the deep-sea? Geochim Cosmochim Acta 59:5031-5036

Dueñas LF, Sanchez JA (2009) Character lability in deep-sea bamboo corals (Octocorallia, Isididae, Keratoisidinae). Mar Ecol Prog Ser 397:11-23

> Duran Muñoz P, Murillo FJ, Sayago-Gil M, Serrano A, Laporta M, Otero I, Gomez C (2011) Effects of deep-sea bottom longlining on the Hatton Bank fish communities and benthic ecosystem, north-east Atlantic. J Mar Biol Assoc UK 91:939-952

Hall-Spencer J, Allain V, Fosså JH (2002) Trawling damage to Northeast Atlantic ancient coral reefs. Proc R Soc Lond B Biol Sci 269:507-511

> Husebø Å, Nottestad L, Fosså JH, Furevik DM, Jorgensen SB (2002) Distribution and abundance of fish in deep-sea coral habitats. Hydrobiologia 471:91-99

> Kim K, Lasker HR (1998) Allometry of resource capture in colonial cnidarians and constraints on modular growth. Funct Ecol 12:646-654

> Koslow JA, Gowlett-Holmes K, Lowry JK, O'Hara T, Poore GCB, Williams A (2001) Seamount benthic macrofauna off southern Tasmania: community structure and impacts of trawling. Mar Ecol Prog Ser 213:111-125

Love MS, Yoklavich MM, Black BA, Andrews AH (2007) Age of black coral (Antipathes dendrochristos) colonies, with notes on associated invertebrate species. Bull Mar Sci 80:391-400

> Mendonça A, Arístegui J, Vilas JC, Montero MF, Ojeda A, Espino M, Martins AM (2012) Is there a seamount effect on microbial community structure and biomass? The case study of Seine and Sedlo Seamounts (Northeast Atlantic). PLoS ONE 7:e29526

> Metaxas A, Davis JE (2005) Megafauna associated with assemblages of deep-water gorgonian corals in Northeast Channel, off Nova Scotia, Canada. J Mar Biol Assoc UK 85:1381-1390

Morgan LE, Etnoyer P, Scholz AJ, Mertens M, Powell M (2005) Conservation and management implications of deep-sea coral distributions and fishing effort in the northeast Pacific Ocean. In: Freiwald A, Roberts JM (eds) Cold-water corals and ecosystems. Springer-Verlag, Berlin, p 1171-1187

Opresko DM (1998) Three new species of Leiopathes (Cnidaria: Anthozoa: Antipatharia) from southern Australia. Rec S Aust Mus (Adel) 31:99-111

OSPAR Commission (2010a) Background document for coral gardens. Publication number 486/2010. OSPAR Commission, London

OSPAR Commission (2010b) Bergen statement. OSPAR Convention for the Protection of the Marine Environment of the North-East Atlantic. Ministerial Meeting of the OSPAR Commission, Bergen: 23-24 September 2010. Available at www.ospar.org/html_documents/ospar/news/ ospar_2010_bergen_statement.pdf

Parrish FA, Roark EB (2009) Growth validation of gold coral Gerardia sp. in the Hawaiian Archipelago. Mar Ecol Prog Ser 397:163-172

Probert PK, Christiansen S, Gjerde KM, Gubbay S, Santos RS (2007) Management and conservation of seamounts In: Pitcher TJ, Morato T, Hart PJB, Clark MR, Haggan N, Santos RS (eds) Seamounts: ecology, fisheries and conservation. Blackwell Publishing, Oxford, p 442-475

> Prouty NG, Roark EB, Buster NA, Ross SW (2011) Growth rate and age distribution of deep-sea black corals in the Gulf of Mexico. Mar Ecol Prog Ser 423:101-115

Reed JK (2002) Deepwater Oculina coral reefs of Florida: biology, impacts, and management. Hydrobiologia 471: 43-55

Reimer PJ, Baillie MGL, Bard E, Bayliss A and others (2009) IntCal09 and Marine09 radiocarbon age calibration curves, 0-50, 000 years cal BP. Radiocarbon 51:1111-1150

Roark EB, Guilderson TP, Flood-Page S, Dunbar RB, Ingram BL, Fallon SJ, McCulloch M (2005) Radiocarbon-based ages and growth rates of bamboo corals from the Gulf of Alaska. Geophys Res Lett 32:L04606

- Roark EB, Guilderson TP, Dunbar RB, Ingram BL (2006) Radiocarbon-based ages and growth rates of Hawaiian deep-sea corals. Mar Ecol Prog Ser 327:1-14

Roark EB, Guilderson TP, Dunbar RB, Fallon SJ, Mucciarone DA (2009) Extreme longevity in proteinaceous deep-sea corals. Proc Natl Acad Sci USA 106:5204-5208

Roberts JM, Wheeler A, Freiwald A, Cairns S (2009) Coldwater corals. Cambridge University Press, New York, NY

Sampaio Í, Braga-Henriques A, Pham C, Ocaña O, de Matos V, Morato T, Porteiro FM (2012) Cold-water corals landed by bottom longline fisheries in the Azores (north 
eastern Atlantic). J Mar Biol Assoc UK 92:1547-1555

Santos RS, Christiansen S, Christiansen B, Gubbay S (2009) Towards the conservation and management of Sedlo seamount: a case study. Deep-Sea Res II 56:2720-2730

Santos RS, Tempera F, Menezes G, Porteiro F, Morato T (2010) Mountains in the sea: Sedlo Seamount, Azores. Oceanography 23:148-149

Sebens KP (1982) The limits to indeterminate growth: an optimal size model applied to passive suspension feeders. Ecology 63:209-222

Sherwood OA, Edinger EN (2009) Ages and growth rates of some deep-sea gorgonian and antipatharian corals of Newfoundland and Labrador. Can J Fish Aquat Sci 66: $142-152$

Sherwood OA, Scott DB, Risk MJ (2006) Late Holocene radiocarbon and aspartic acid racemization dating of deepsea octocorals. Geochim Cosmochim Acta 70:2806-2814

Sherwood OA, Jamieson RE, Edinger EN, Wareham VE (2008) Stable C and N isotopic composition of cold-water corals from the Newfoundland and Labrador continental slope: examination of trophic, depth and spatial effects. Deep-Sea Res I 55:1392-1402

Soares AMM, Martins JMM (2010) Radiocarbon dating of marine samples from the Gulf of Cadiz: the reservoir effect. Quat Int 221:9-12

Stuiver M (1980) ${ }^{14} \mathrm{C}$ distribution in the Atlantic Ocean. J Geophys Res 85(C5):2711-2718

Stuiver M, Polach HA (1977) Discussion: reporting of ${ }^{14} \mathrm{C}$ data. Radiocarbon 19:355-363

Editorial responsibility: Karen Miller,

Hobart, Tasmania, Australia
Stuiver M, Reimer PJ (1993) Extended ${ }^{14} \mathrm{C}$ data base and revised Calib $3.0{ }^{14} \mathrm{C}$ age calibration program. Radiocarbon 35:215-230

Tempera F, Giacomello E, Mitchell N, Campos AS and others (2012) Mapping the Condor seamount seafloor environment and associated biological assemblages (Azores, NE Atlantic). In: Baker E, Harris P (eds) Seafloor geomorphology as benthic habitat. Geohab atlas of seafloor geomorphic features and benthic habitats. Elsevier, London, p $807-818$

Tisnérat-Laborde N, Paterne M, Metivier B, Arnold M, Yiou P, Blamart D, Raynaud S (2010) Variability of the northeastern Atlantic sea surface $\Delta^{14} \mathrm{C}$ marine reservoir age and the North Atlantic Oscillation (NAO). Quat Sci Rev 29:2633-2646

Tracey DM, Neil H, Marriott P, Andrews AH, Calliet GM, Sanchez JA (2007) Age and growth of two genera of deep-sea bamboo corals (family Isididae) in New Zealand waters. Bull Mar Sci 81:393-408

Vilas JC, Arístegui J, Kiriakoulakis K, Wolff GA and others (2009) Seamounts and organic matter-Is there an effect? The case of Sedlo and Seine Seamounts: Part 1. Distributions of dissolved and particulate organic matter. DeepSea Res II 56:2618-2630

> Watling L, France SC, Pante E, Simpson A (2011) Biology of deep-water octocorals. Adv Mar Biol 60:41-122

> Williams B, Risk MJ, Ross SW, Sulak KJ (2006) Deep-water antipatharians: proxies of environmental change. Geology $34: 773-776$

Submitted: December 6, 2011; Accepted: September 17, 2012 Proofs received from author(s): December 28, 2012 